\title{
MYELOSIS INVOLVING THE GRANULOCYTIC AND ERYTHROCYTIC SYSTEMS
}

\author{
BY \\ GEORGE DISCOMBE AND KENNETH NICKOL \\ From the Central Middlesex Hospital, London
}

(RECEIVED FOR PUBLICATION DECEMBER 11, 1953)

There are several syndromes in which an erythrsblastic reaction, comparable with the granulocytic reaction of granulocytic leukaemia, is prominent. One is the "leukanaemia" of von Leube (1900) defined by Foy, Kondi, and Murray (1946) as " a haematological condition in which there co-exist a pernicious anaemia-like and a leukaemia-like blood picture with corresponding marrow disorder of the erythroid and myeloid issues"; they conclude that " as a disease sui generis [it] does not exist, being either atypical pernicious anaemia or atypical myeloid (usually myeloblastic) leukaemia." Garnier, Cordier, and Sigwalt (1941) described a variant unusual in its intensity, and many other variants may be found in the French and Italian literature. Anglo-Saxon writers rarely describe such cases, for they usually regard the erythroblastosis or the granulocytic reaction, as the case may be, as symptomatic epiphenomena of little importance, and "erythroleukaemia" and "leukanaemia" are dismissed each in 15 to 20 lines by Whitby and Britton (1950).

However, Di Guglielmo (1945) has brought forward evidence which suggests that the acute and chronic erythraemic myeloses which bear his name may well prove to be disease entities he also describes an erythroleukaemia which can be difficult to differentiate from erythraemic myelosis on the one hand and leukanaemia on the other. Acute erythraemic myelosis, always fatal within two months of onset (Di Guglielmo, 1923, 1926, 1945), is characterized by anaemia, fever, splenomegaly proportionally greater than hepatomegaly, and proliferation in marrow, spleen, lymph nodes, and liver of dysplastic erythroblasts which fail to mature. The nuclei of these cells are usually megaloblastoid or reticuloendothelioid. The chronic form (Duesberg, 1940; Heilmeyer and Schöner, 1941 ; Di Guglielmo and Quattrin, 1942) has a more chronic course, up to two years, and the peripheral blood erythroblasts are orthochromatic. It is the only form so far described in England (Israëls, 1939 ; Neumark,
1949 ; Emery, 1951). In erythroleukaemia hepatomegaly may be more marked than splenomegaly, and erythroblastosis, though it persists till death, is more intense at the beginning of the disease, giving place to the uncontrolled proliferation of primitive granulocytes which may have grossly atypical, histiocytic nuclei.

Recently, evidence has been accumulating that erythraemic myelosis and erythroleukaemia may be unusual modes of onset of acute leukaemia (Bussi and Franzini, 1951; Rachet, Mallarmé, and Bourel, 1951; Mallarmé and Bourel, 1951). It appears that the longer the patient survives, the more likely is he to develop the classical picture of acute granulocytic leukaemia, and now that intensive transfusion is so commonly practised patients with leukaemia-like syndromes rarely die from anaemia in the early stages of the disease, so that the change from erythraemic myelosis to leukaemia is more commonly seen. Nevertheless, patients still die with the picture of erythraemic myelosis (Emery, 1951; Schwartz and Critchlow, 1952). It seems as yet uncertain whether erythroleukaemia will have to be separated from erythraemic myelosis, or whether these "diseases" can be grouped together as unusual variants of acute granulocytic leukaemia. The case recorded here appeared at first to be erythraemic myelosis, but ultimately had to be classed as erythroleukaemia, resembling closely the case of Verloop, Deenstra, and van der Hoeven (1952).

\section{Case History (No. 10272/52)}

A man aged 72, who had previously never been ill, noticed lassitude and dyspnoea from January, 1952, became increasingly weak, short of breath, and developed pain in the chest on exertion from March, 1952, and collapsed in the street about the end of April. He refused to enter hospital. He did not improve and his weakness became so extreme that he was scarcely able to leave his bed. On admission on June 3, 1952, he was very pale, had a black tongue, enlarged cervical and axillary lymph nodes, and oedema of both ankles. The liver was palpable 3 in. $(8 \mathrm{~cm}$.) below the costal margin, 


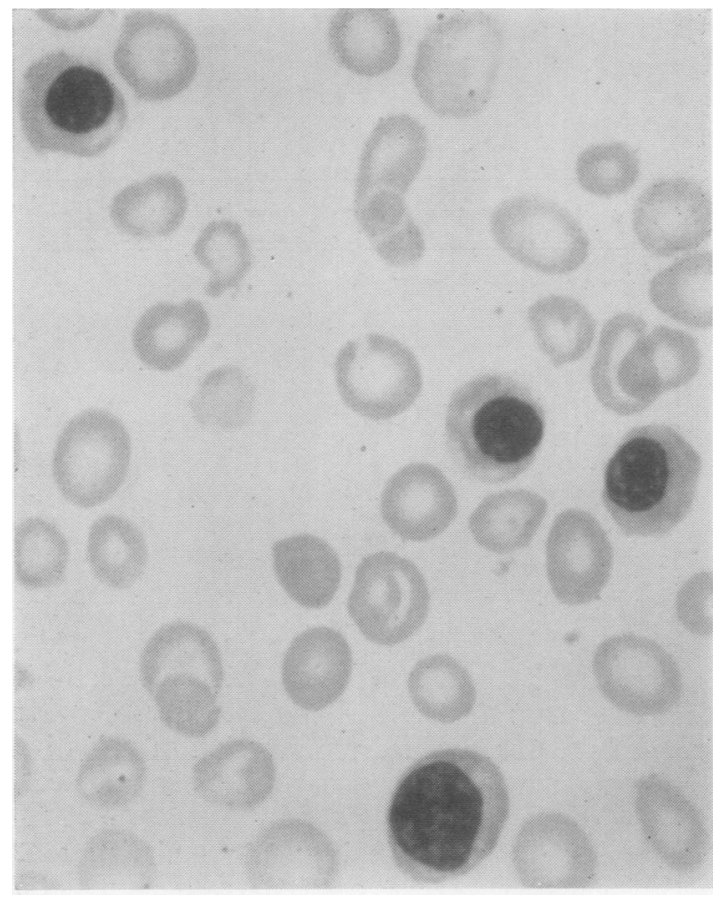

but the spleen could not be palpated. The apex beat was $\frac{1}{2}$ in. $(1.5 \mathrm{~cm}$.) outside the mid-clavicular line, and a gallop rhythm was present, though no abnormal sounds were heard (pulse 96 , blood pressure $182 / 90 \mathrm{~mm}$. $\mathrm{Hg}$ ). The blood count ( $\mathrm{Hb} 4.7 \mathrm{~g}$., nucleated red cells 26,200 per c.mm.) and sternal marrow were considered diagnostic of a subacute erythraemic myelosis (Tables I and II).

The course was progressively downhill in spite of $\overrightarrow{\mathbb{D}}$ transfusion. On June 10 he had ecchymoses of the hard palate and a petechial rash on the face. Blood oozed from every prick, in spite of a platelet count of 230,000 per c.mm. Low-grade fever up to $99^{\circ} \mathrm{F}$. developed. Slight improvement occurred during the next week, but on June 18 he had an epileptiform attack in which a tooth was knocked out ; in spite of stitching the socket,

TABLE I

PERIPHERAL BLOOD

\begin{tabular}{|c|c|c|c|c|c|}
\hline Cell Type & June 3 & June 21 & July 8 & July 14 & July 22 \\
\hline $\begin{array}{l}\text { Leucocytes } \\
\begin{array}{l}\text { Myeloblasts } \\
\text { Erythroblasts }\end{array} \\
\text { \% of normoblasts : } \\
\text { Pro- } \\
\begin{array}{l}\text { Basophilic } \\
\text { Polychromatic }\end{array} \\
\text { Orthochromatic }\end{array}$ & $\begin{array}{r}2,100 \\
850 \\
26,200 \\
\\
4 \cdot 5 \\
7 \cdot 5 \\
35 \\
53\end{array}$ & $\begin{array}{r}745 \\
100 \\
4,500 \\
\\
2 \cdot 5 \\
8 \cdot 5 \\
15 \cdot 5 \\
73 \cdot 5\end{array}$ & $\begin{array}{r}2,550 \\
100 \\
215 \\
- \\
= \\
100\end{array}$ & $\begin{array}{l}2,440 \\
\overline{428} \\
2 \overline{1 \cdot 5} \\
42 \cdot 5 \\
36\end{array}$ & $\begin{array}{r}10,000 \\
1,380 \\
5,570 \\
\\
17 \\
38 \cdot 5 \\
44 \cdot 5\end{array}$ \\
\hline
\end{tabular}

Fig. 1.-Film of peripheral blood on admission

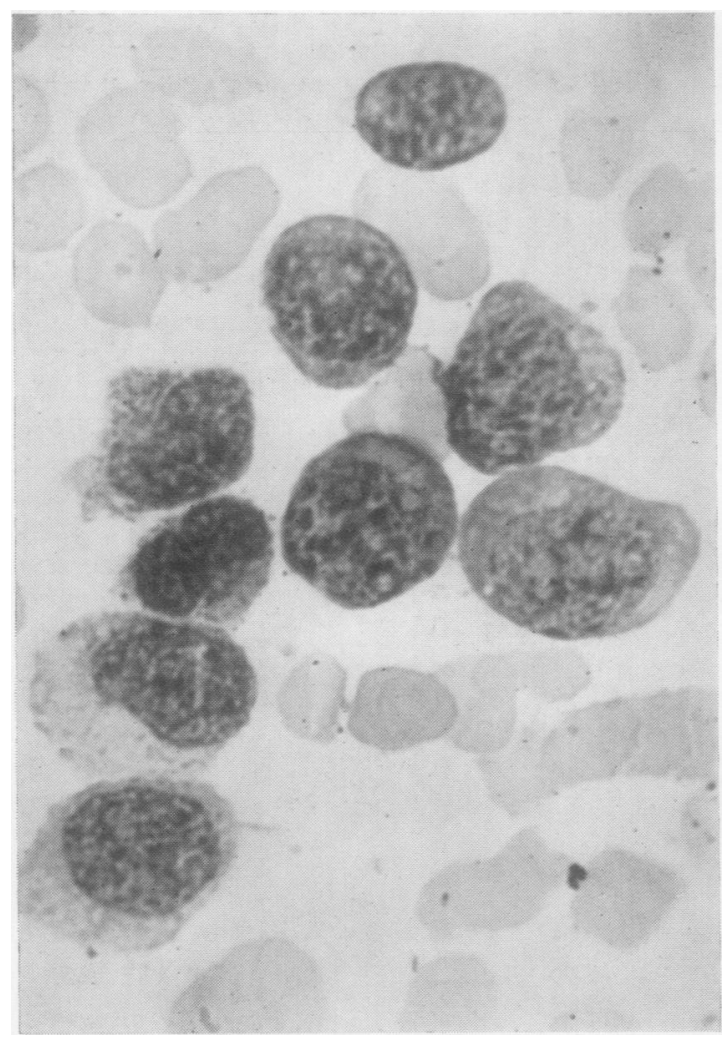

FIG. 2a.

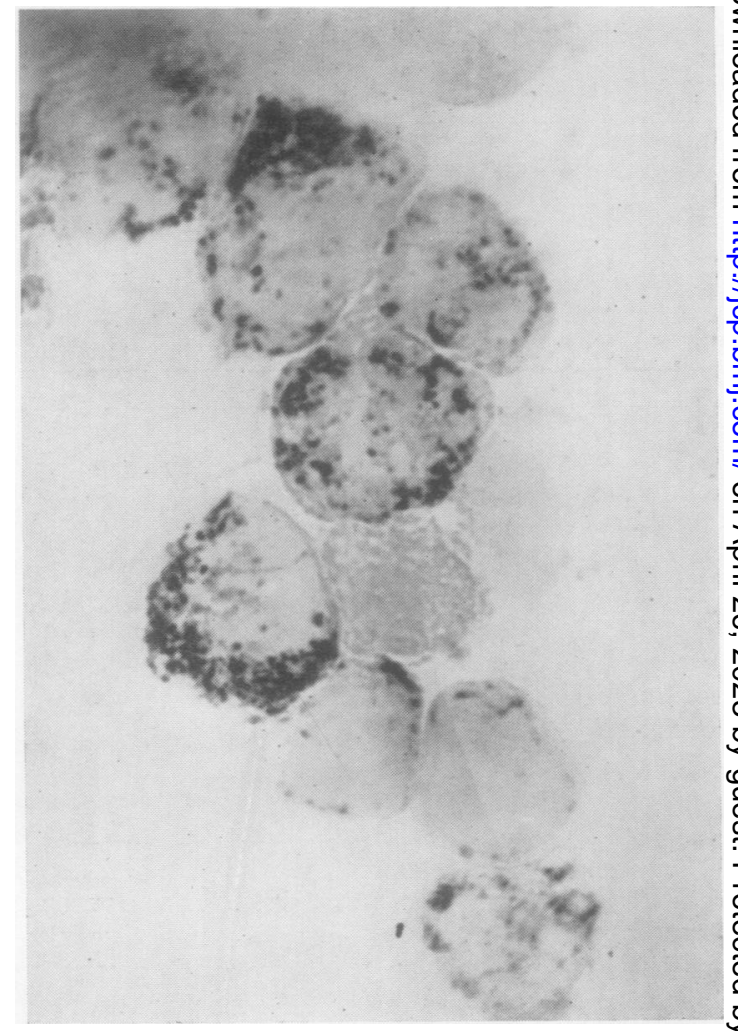

FiG. 2b.

FIG. 2.-Marrow films taken on day of death: (a) Leishman, (b) peroxidase stain. Nearly all cells contain granules. 


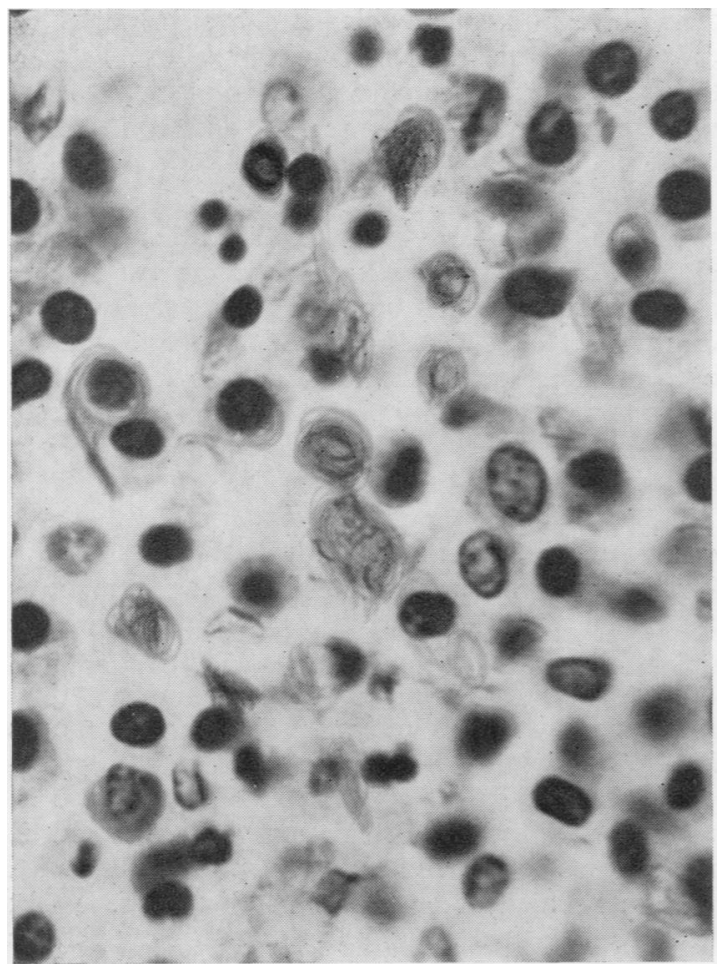

FiG. 3a.

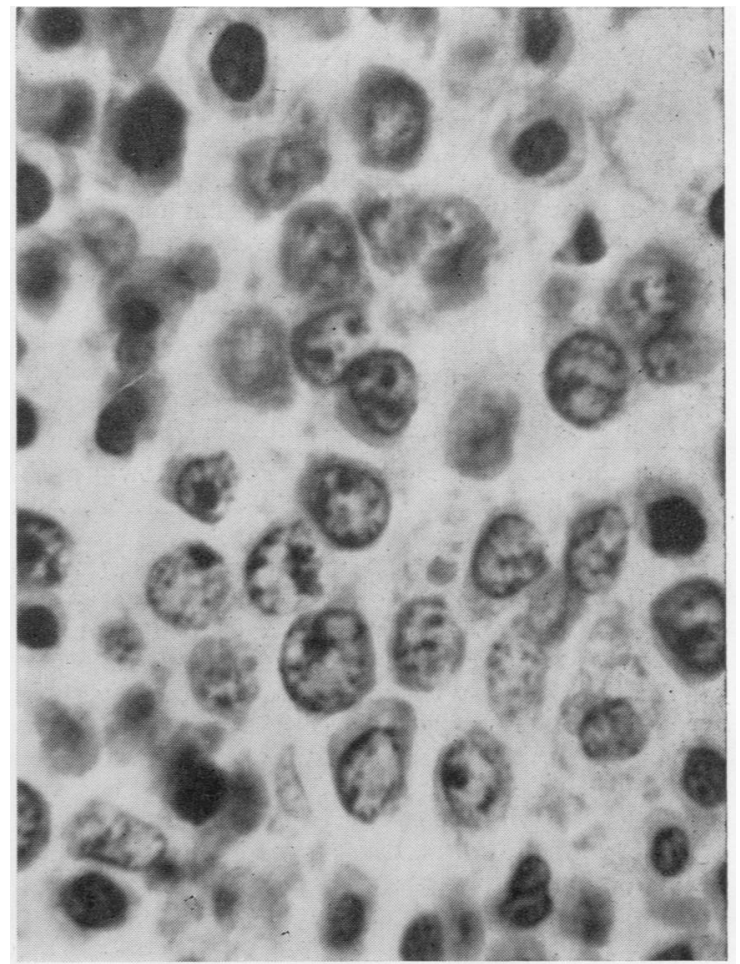

FIG. 3b.

Fig. 3.-Necropsy material. (a) and (b) sections of bone marrow.

TABLE II

MARROW DIFFERENTIAL COUNTS

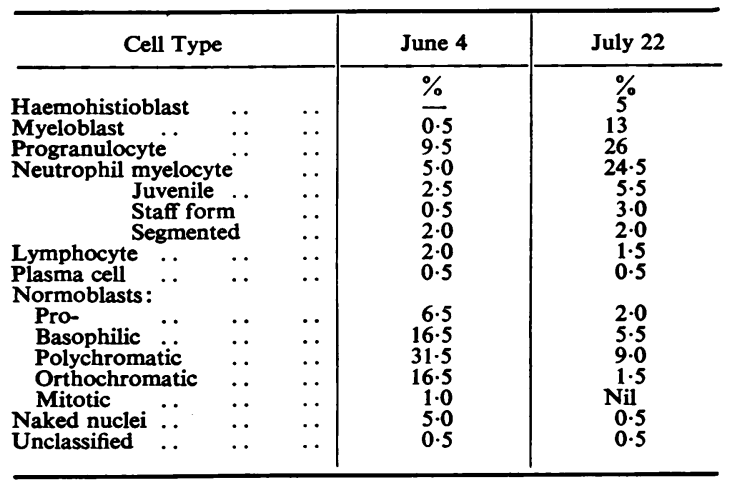

blood oozed continuously from it until death. On June 25 he had a melaena stool. On July 3 he was transfused up to $13.0 \mathrm{~g}$. Hb $(88 \%)$ with symptomatic improvement, but on July 8 he developed haematuria and a sub-conjunctival haemorrhage; intermittent bleeding from these sites continued until death on July 22 , about seven months after the clinical onset, he having received 13.5 litres of stored blood during the last 50

days of life. His sister had died of monocytic leukaemia in Hammersmith Hospital in 1943.

Haematology. - The data are summarized in the tables and Figs. 1-3. The patient was admitted with anaemia, a reticulocytosis of $31 \%$, and erythroblastaemia, the erythroblasts being mainly orthochromatic and showing karyorrhexis and a few mitotic figures. On June 10 the platelet count was 230,000 per c.mm. Leucocyte and erythroblast counts gradually fell until on June 8 primitive cells of either series were scanty; thereafter both increased and primitive cells became abundant, most clearly seen in the marrow of July 22 (vide infra).

Necropsy.-Necropsy showed petechial haemorrhages in the skin, pia mater, pericardium, endocardium, parietal and visceral peritoneum and pleura, gastrointestinal tract, renal pelvis, and ureter.

The bone marrow was red and hyperplastic (sternum, ribs, femur, and vertebrae).

Lymph nodes of the cervical, axillary, para-aortic, mediastinal, pelvic, and inguinal groups were enlarged to about $1 \mathrm{~cm}$. diameter : they remained discrete, were soft, and the cut surface was red.

The liver $(1,930 \mathrm{~g}$.) was pale and rather greasy in appearance ; the normal architecture was preserved.

The spleen $(217$ g.) was soft, pink, and patchily congested. 
The kidneys (L. 155 g., R. 135 g.) showed narrowed cortex and pale, mottled, cut surfaces.

The heart $(470 \mathrm{~g}$.) showed a rather fatty myocardium, the left ventricle being dilated and hypertrophied (wall $2 \mathrm{~cm}$. thick). The coronary arteries showed little atheroma except $3 \mathrm{~cm}$. from the ostium of the right coronary artery, where there had been subintimal bleeding at an atheromatous plaque. Other organs showed no gross abnormality.

Histology.-The myocardium shows some degenerative pigment.

The tongue and pituitary show no significant abnormality.

A kidney shows patchy leukaemic infiltration in cortex and medulla, and the suprarenals show granular deposits of pigment which does not contain iron, and a few foci of leukaemic cells.

The portal tracts of the liver are infiltrated by leukaemic cells; the parenchymal cells are swollen, and many contain droplets of bile pigment and granules of haemosiderin. The sinusoids contain leukaemic cells.

The bone marrow is extremely cellular, and very few typical myeloid or erythroid cells are present. A few reticulum cells are present, but the predominating cell is a rounded or polyhedral cell forming dense sheets. It has a copious, very finely granular, eosinophilic cytoplasm, with a central dense hyperchromatic nucleus, sometimes so dense as to suggest pyknosis. Some nuclei, however, are less dense and more vesicular, and these have usually less intensely eosinophilic cytoplasm. There are no cells with the typical morphology of myeloblasts.

The lymph nodes show (1) diffuse hyperplasia of cells resembling those of the bone marrow, which also infiltrate the capsule, and (2) areas of necrosis, among which are "follicles" made up of cells resembling those of the bone marrow. Staining of frozen sections by a benzidine blue method shows that the "follicles" are surrounded by cells containing many lipoid granules, which cells are also found in and around the necrotic areas: tnese cells are obviously not polymorphs but appear to be myelocytes or histiocytes.

In the spleen the Malpighian bodies are small and inconspicuous, separated by a slightly congested pulp. Reticulum cells are scanty, histiocytes are more numerous, but the sinusoids are filled witn cells resembling those of the bone marrow, and islands of cells resembling typical normoblasts are present. There is no erythrophagocytosis, but much haemosiderin is present.

\section{Discussion}

Great difficulty was encountered in analysing the cytology of the bone marrow from sections, even though these were cut from material aspirated only half an hour after death. The predominating cell, described above, resembled no cell hitherto seen in the acute laekaemias, but bore somewhat greater resemblance to an erythroblast showing arrested maturation at the early polychromatic stage. Study of smears of the same marrow, stained by Leishman's stain and Sato and Sekiya's peroxidase reaction, led to quite different conclusions-that about $75 \%$ of the marrow cells were of the granulocytic series, promyelocytes, or myelocytes A and B on Sabin's classification.

At first inspection the predominating nuclear pattern of cells in the marrow film resembles most closely a megaloblast, with rather coarse reticulation, at the nodes of which occur large, apparently solid lumps of chromatin. However, some of these cells, even the most basophilic ones whose nuclei contain obvious nucleoli, contain also azurophil cytoplasmic granules, which are extremely rare in megaloblasts ; and, in the peroxidase-stained film, approximately $75 \%$ of the cells were peroxidase positive. More critical examination indicated that the "megaloblastic" or " reticulo-endothelioid " appearance of the nuclei was due to two factors : (1) the presence of unusually numerous heterochromatic bodies (which are more conspicuous in megaloblasts than in other cells), and (2) the presence of many granules in the cytoplasm - large compared with mitochondria and some azurophilic. These granules, together with the mitochondria, underlie and overlie the nucleus and indent it, producing the stippled pattern normally seen in "blasts" (Jones, 1948) ; because of their unusually large size the stippling is unusually coarse, even coarser than is usually seen in megaloblasts and comparable with that seen in haemohistioblasts and reticulum cells.

It was surprising to note that few cells were intensely basophilic in spite of the active proliferation which appeared to be taking place.

It becomes ever more obvious that haemocytological studies are reliable only when based on smears or imprints of material obtained during life.

\section{Conclusion}

If we accept the validity of describing disease entities of "leukanaemia," " erythroleukaemia," " acute erythraemic myelosis," our patient must be regarded as suffering from subacute erythroleukaemia. Many observers doubt whether these distinctions are valid, considering that these names describe modes of onset of acute granulocytic leukaemia between which no sharp distinction can be drawn, and that the appearance of erythroblasts should be regarded as an epiphenomenon whose chief importance is that it makes diagnosis more difficult (see Rodellec Du Porzic, 1938 ; Lüdin, 1950 ; Sarrailhé, 1951 ; Bussi and Franzini, 1951; Mallarmé and Bourel, 1951, for the development of this idea). Further analysis of this concept must await the recognition of more cases. 


\section{Summary}

A man aged 72 developed anaemia and died about 12 weeks from the onset of symptoms.

The anaemia was characterized by intense erythroblastaemia and reticulocytosis, with marrow erythroblastosis, and a haemorrhagic state: a diagnosis of Di Guglielmo's erythraemic myelosis was accepted.

At death the patient was found to have changes characteristic of acute granulocytic leukaemia.

We wish to thank Dr. Richard Asher for permission to describe this patient, who was under his care.

\section{REFERENCES}

Bussi, L., and Franzini, P. (1951). Haematologica, 35, 661.
Di Guglielmo, G. (1923), In Ferrata, A., Le Emopatie. Milan. (1926). Boll. Soc. med.-chir., Pavia, 40, 665.

(1945). Le Malattie Eritremiche. Rome.

and Quattrin, N. (1942). Haematologica, 24, 1.

Duesberg, R. (1940). Klin. Wschr., 19, 417.

Emery, J. L. (1951). J. Path. Bact., 63, 395.

Foy, H., Kondi, A., and Murray, J. F. (1946). Ibid., 58, 157.

Garnier, Cordier, and Sigwalt (1941). Sang, 14, 579.

Heilmeyer, L., and Schöner, W. (1941). Dtsch. Arch. klin. Med., 187, 225.

Israëls, M. C. G. (1939). J. Path. Bact., 48, 299.

Jones, O. P. (1948). Blood, 3, 967.

Leube, W. von (1900). Berl. klin. Wschr., 37, 851

Lüdin, H. (1950). Acta haemat., Basel, 4, 321.

Mallarmé, J., and Bourel (1951). Sang, 22, 586.

Neumark, E. (1949) In Bone Marrow Biopsy, p. 167-8, by S. J. Leitner. Translated and edited by C. J. C. Britton and E. Neumark. Churchill, London.

Rachet, Mallarmé, and Bourel (1951). Sang, 22, 582.

Rodellec Du Porzic, M. de (1938). L'erythromyelose alguë. Thèse de Paris.

Sarrailhé, A. (1951). Sang, 22, 584.

Schwartz, S. O., and Critchlow, J. (1952). Blood, T, 765.

Verloop, M. C., Deenstra, A., and Hoeven, L. H. van der (1952). Ibid., 7, 454 .

Whitby, L. E. H., and Britton, C. J. C. (1950). Disorders of the Blood, 6 th ed., pp. 445 and 488-9. Churchill, London. 